\title{
Formation of Sustainable Investment Attractiveness of Regions Under the Conditions of COVID-19
}

\section{Kształtowanie zrównoważonej atrakcyjności inwestycyjnej regionów w warunkach pandemii COVID-19}

\section{Tetiana Polozova*, Yurii Kutsenko**, Oleksandra Kanova ${ }^{\star \star \star}$}

\author{
*Kharkiv National University of Radio Electronics, \\ Department of Economic Cybernetics and Management of Economic Security, Kharkiv, \\ Nauky Avenue, 14, 61166 Ukraine \\ E-mail: tetiana.polozova@nure.ua,ORCID:0000-0001-9956-8816 \\ ** Kharkiv National University of Radio Electronics, \\ Department of Economic Cybernetics and Management of Economic Security, \\ Kharkiv, Nauky Ave., 14, 61166 Ukraine \\ E-mail: kutsenko.yurii85@gmail.com, ORCID:0000-0003-1081-1088 \\ ***Simon Kuznets Kharkiv National University of Economics, \\ Department Management and Business, \\ Kharkiv, Nauky Avenue, 9-A, 61166 Ukraine \\ E-mail: oleksandra.kanova@hneu.net, ORCID:0000-0002-0101-053X
}

\begin{abstract}
The decline in the forecast indicators of the economy and production activity, the structural transformation of international production and consumer preferences, the reduction in income from bonds and world tourism, the massive layoffs of workers that led to an increase in unemployment and a decrease in household income, deferred investments and the reorientation of investment flows, both in economic sectors and in the regional context, are all the result of the impact of another challenge called Covid-19. The Covid-19 pandemic has changed and continues to change many characteristics of the economy and society. Together with the onset of the Fourth Industrial Revolution and the transition to the digital era, as well as taking into account completely new realities of the development of future generations, which are regulated by the concept of sustainable development, the formation of investment attractiveness is also taking place in a fundamentally different way. In this regard, the article substantiates the need to introduce the category sustainable investment attractiveness into everyday use. The author's vision of the interpretation of this concept is presented. A procedure for forming a stable investment attractiveness of regions in the conditions of Covid-19 has been developed.
\end{abstract}

Key words: investment risks, investment potential, sustainable investment attractiveness of regions, sustainable development, Covid-19

\section{Streszczenie}

Spadek prognozowanych wskaźników gospodarki i działalności produkcyjnej, strukturalne przekształcenia produkcji międzynarodowej i preferencji konsumentów, zmniejszenie dochodów z obligacji i światowej turystyki, masowe zwolnienia pracowników, które doprowadziły do wzrostu bezrobocia i spadku dochodów gospodarstw domowych, odroczone inwestycje i reorientacja przepływów inwestycyjnych, zarówno w sektorach gospodarki, jak i w kontekście regionalnym, są wynikiem wpływu wyzwań pandemii Covid-19. Zmieniła ona i nadal zmienia wiele cech gospodarki i społeczeństw. Wraz z nadejściem czwartej rewolucji przemysłowej i przejściem do ery 
cyfrowej, a także uwzględniając zupełnie nowe realia rozwoju przyszłych pokoleń, które reguluje koncepcja zrównoważonego rozwoju, kształtowanie się atrakcyjności inwestycyjnej odbywa się również w zupełnie inny sposób. W tym zakresie artykuł uzasadnia potrzebę wprowadzenia do codziennego użytku kategorii zrównoważonej atrakcyjności inwestycyjnej. Została przedstawiona autorska wizja interpretacji tego pojęcia. Opracowano także procedurę kształtowania stabilnej atrakcyjności inwestycyjnej regionów w warunkach Covid-19.

Slowa kluczowe: ryzyka inwestycyjne, potencjał inwestycyjny, zrównoważona atrakcyjność inwestycyjna regionów, zrównoważony rozwój, Covid-19

\section{Introduction}

One of the key conditions for the development of any socio-economic system is the availability of investments as an important source of economic growth of the state. The global problems of humanity, which are primarily related to the political, environmental, economic and social crisis, including the global coronavirus pandemic, create significant obstacles in the processes of attracting investment.

Thus, according to the report on world investments 2020, prepared within the framework of the United Nations Conference on Trade and Development UNCTAD, $19 \%$ of projects involving foreign direct investment (FDI) in Europe were canceled, another $25 \%$ were frozen, half of the investors were going to reduce the investment volumes planned for 2020 by $10-15 \%$ (UN). In addition, the analysis presented in the report shows that in four of the ten key areas of sustainable development (SD), the inflow of international private sector investment has not increased significantly since the adoption of the goals in 2015. European countries, having a significant natural resource potential and high-quality human capital, are experiencing difficulties in attracting investment. The lever of changing this situation can be organizational and methodological support and practical stimulation of the investment attractiveness of regions, the success of which depends on the joint actions of science and practice.

Taking into account the fact that investment attractiveness is a characteristic that reflects the quality of the macroeconomic environment and its ability to meet the requirements of modern realities, the activation of investment activity of economic entities creates prerequisites for introducing innovations, optimizing production, increasing and updating production capacities, expanding existing and conquering new sales markets, fulfilling the strategic tasks aimed at the implementation of the SDGs. In this regard, there is a need to rethink the existing theoretical and methodological approaches and applied aspects of the formation of investment attractiveness of regions in the conditions of Covid-19, the implementation of which will bring us closer to sustainable development.

The purpose of the article is to develop theoretical, methodological foundations and practical recommendations for the formation of investment attractiveness of regions under the conditions of Covid-19.

\section{Findings and Discussion}

2.1. Formation of sustainable investment attractiveness of regions under the conditions of Covid-19: theoretical and analytical aspect

Successful implementation of regional investment activities is possible if there is a certain investment attractiveness of the territory. In modern science, the limits of the interpretation of the concept of investment attractiveness are not defined. They begin with its identification with the investment climate (L. Borshch, S. Herasymova 2007), and end with the solvency of the territory for investments (A. Nosova, Y. Krylov, 2003; K. Mamonova, 2008; S. Vdovin, 2014), which creates prerequisites for the formation of the author's vision regarding this category.

Analysis of the fundamental works of foreign authors Robert B. Stoby, A. (1969) Bevan, S. Estrin, K. Meyer (2000), J. Hellman, J. Johnson, D. Kaufman, M. Shankerman (2000), D. Holland (1998), J. Janssen (2001), allowed us to establish that scientists use the term investment climate only in the field of international financial markets.

The etymology of the concepts of investment climate and investment attractiveness indicates that they differ in content. The concept of climate, in a narrow sense, means the initial conditions (Geographical Encyclopedia), therefore, the climate is not a cause, but a consequence, which means that in order to attract investment, certain conditions must be met, as well as they must satisfy all parties (depositors, beneficiaries). Such a condition is the attractiveness of the territory (its capabilities), which determines the priority directions of the region's development. Thus, investment climate and investment attractiveness should be considered as separate categories.

A review of scientific research led to the conclusion that a number of authors, such as Y. Zadorozhna L. Diachenko (2007); T. Bezrukova, I. Shanin, Y. Ziborov (2015), consider the investment attractiveness at the macro and micro levels. Moreover, they refer to the investment climate (state and region) at the macro level, and the micro level is the investment attractiveness (industry, enterprise). When discussing this statement, it turns out that a state or a region cannot have investment attractiveness, but only an investment climate, and vice versa - the industry and the enterprise can be characterized only from the point of view of investment attractiveness. This approach does not allow us to display the full range of 


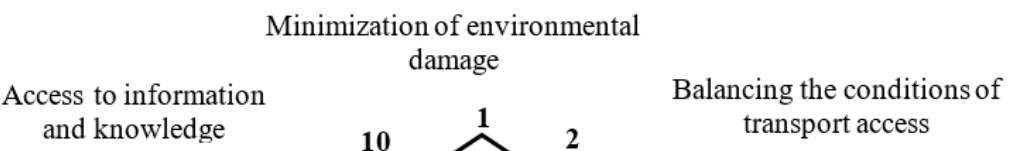

Encouraging the development generated by urban functions and improving the relationship between the city and the village

Multiplication of cultural 8 heritage as a factor of development Promoting high-quality
sustainable tourism

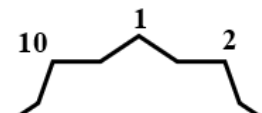
transport access

Principles of

Ensuring territorial harmony through balanced socioeconomic development and increasing their competitiveness

development of

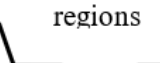

Enhancement and protection of natura
resources and natural heritage

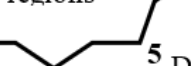

5 Development of safe extraction of energy resources

Limitations of the

consequences of natural

disasters

Figure 1. Fundamental principles of sustainable development of regions, compiled by the authors on the basis of Guiding Principles for Sustainable Development of the European Continent (2000)

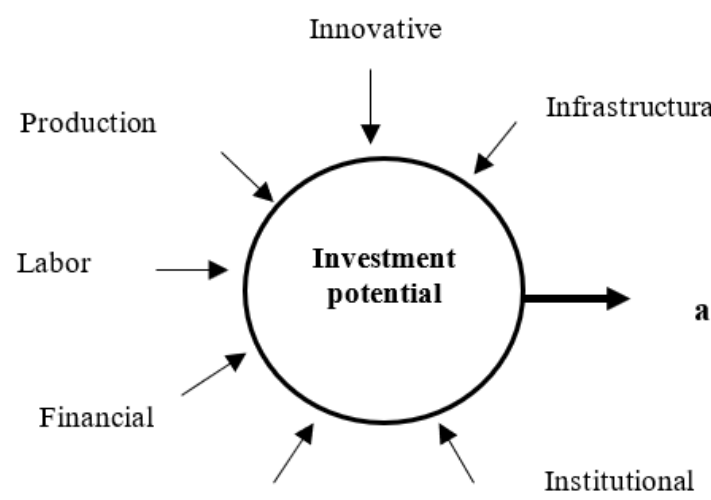

Foreign economic

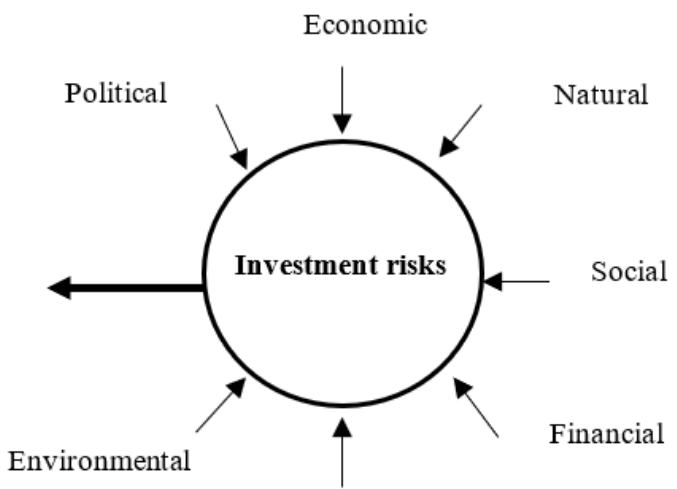

Legislative

Figure 2. A figurative model of the formation of investment attractiveness of regions before the Covid-19 pandemic, compiled by the authors on the basis of Lavresh I., Myronov V., Smirnov A. (2011)

impact factors and narrows the set of indicators for evaluating capital investments, which in turn makes it difficult to practically rank regions by the degree of investment attractiveness.

Makarii N. calls the fair quantitative and qualitative characteristics of the external and internal environment of the object of potentially possible investment as investment attractiveness (Makarii, 2001). In the studies of I. Hryshyn, A. Shakhnozarov, I. Roizman (2001) investment attractiveness is considered through the combination of investment potential and investment risks. The investment attractiveness of the region determines the investment activity. At the same time, the authors understand investment activity as the intensity of attracting investment in the fixed capital of the region. Then the investment climate is a symbiosis of investment activity and attractiveness. A similar point of view is reflected in the studies of A. Asaul, I. Pasiada (2004), V. Kiriukhin (2006).

Thus, the presented generalization of scientific points of view allows us to conclude that investment attractiveness determines the vectors of investment movement. It is, on the one hand, factorial, and, on the other hand, resultant, i.e. it creates prerequisites for increasing investment activity. In this regard, the investment attractiveness of the region should be un- derstood as a combination of investment potential (conditions and opportunities) and risks affecting the volume of attracted capital carried out on mutually beneficial terms with investors.

The investment potential in the article refers to the region's opportunities for sustainable development, that is, the investment potential allows us to form a vision regarding the region's readiness to receive investments with appropriate guarantees of capital preservation and profit for investors based on the principles of regional sustainable development (Fig. 1).

It should be noted that the investment potential of the region is represented by various types of resources: economic, foreign economic, production, labor, innovation, infrastructure, financial, institutional, etc. The formation of investment attractiveness of regions is carried out under the influence of various groups of risks: political, social, economic, environmental, and other risks that change over time as well as the strength of their impact changes (increases or decreases). Schematically, the formation of investment attractiveness can be represented as follows (Fig. 2).

The generalization of scientific points of view in the field of risks of forming the investment attractiveness of regions allowed us to establish the existence 


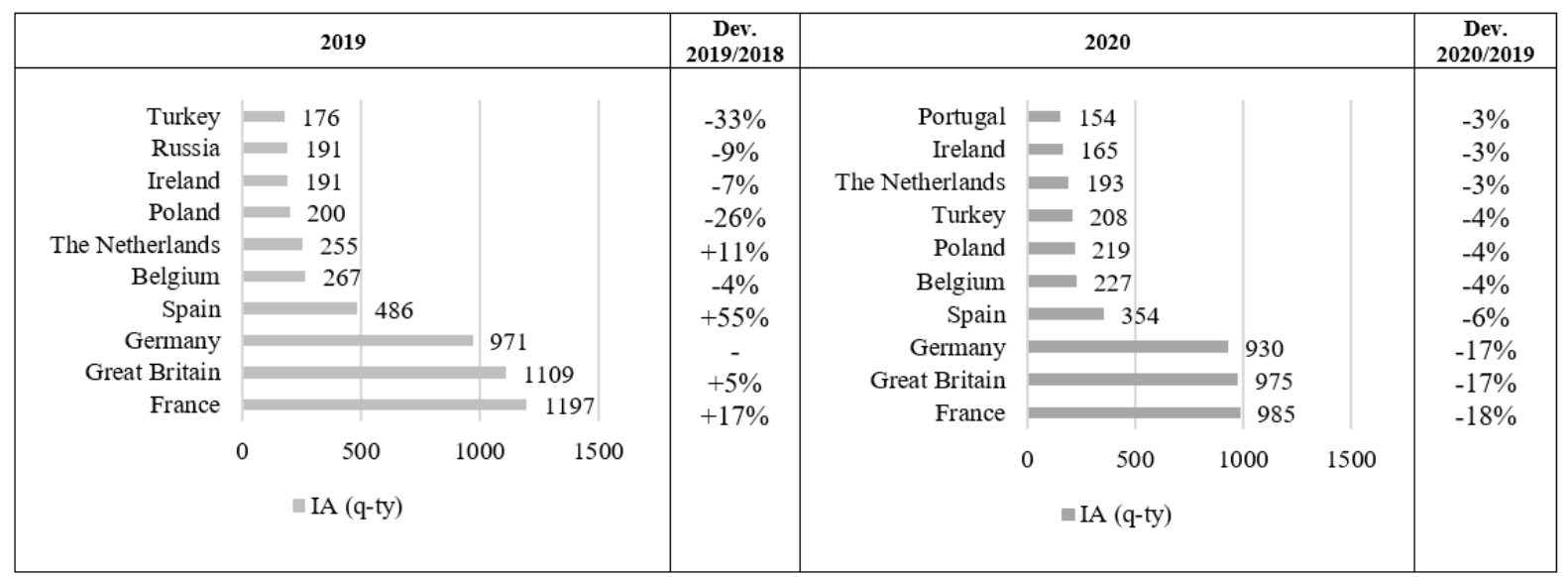

Figure 3. Dynamics of investment attractiveness in European regions before and during Covid-19, compiled by the authors on the basis of $\mathrm{EY}(2018,2019,2020)$

\begin{tabular}{|c|c|c|c|}
\hline Number of projects in 2019 & \begin{tabular}{|c|} 
Dev. \\
$2019 / 2018$ \\
\end{tabular} & Number of jobs in 2019 & $\begin{array}{c}\text { Dev. } \\
2019 / 2018\end{array}$ \\
\hline 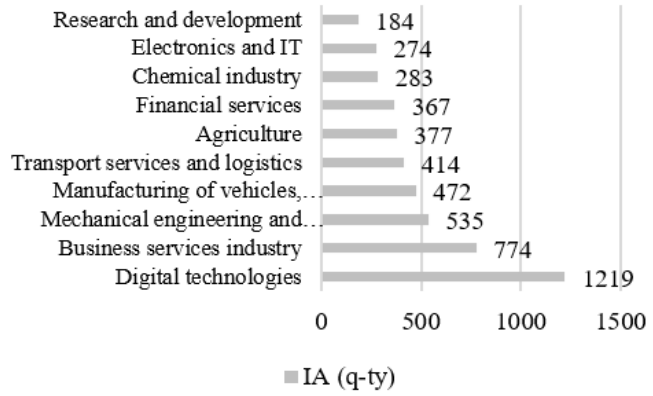 & $\begin{array}{l}+3 \% \\
+4 \% \\
+4 \% \\
+6 \% \\
+6 \% \\
+6 \% \\
+7 \% \\
+8 \% \\
+12 \% \\
+19 \%\end{array}$ & \begin{tabular}{r|c|c|} 
Research and... & 6249 & \\
Electronics and IT & 16741 & \\
Chemical industry & 6955 & \\
Financial services & 6126 & \\
Agriculture & 11392 & \\
Transport services... & 22183 & \\
Production of.. & & \\
Mechanical.. & 16512 & \\
Business services... & 25601 & \\
Digital technologies & & 41025 \\
& 0 & 20000400006000080000 \\
&
\end{tabular} & $\begin{array}{l}+2 \% \\
+6 \% \\
+3 \% \\
+2 \% \\
+4 \% \\
+8 \% \\
+23 \% \\
+6 \% \\
+9 \% \\
+15 \%\end{array}$ \\
\hline
\end{tabular}

Figure 4. Investment attractiveness of industries during Covid-19, compiled by the authors on the basis of EY $(2019,2020)$

of various classifications that were proposed by the authors taking into account their own scientific interests. Some people divide the entire set of risks according to two criteria: 1) according to the method of influencing the economic growth of investment attractiveness and 2) depending on the final goals of the regions (Nechytailo, 2011; Haidutskyi, 2004; Hukaliuk, Ivanovych, 2010; Kuzmyn, Komarnytskyi, 2002; Khusainov, 2015, etc.). Other authors consider the current order of income distribution between economic entities in society as the dominant risk of forming the investment attractiveness of the country (J. Janssen, 2001 P. Masset, 1971 Juha, 2017). Still others believe that risks in the formation of investment attractiveness of regions should be considered through competitive advantages (Miakshyn, 2014; Moghoiev, 2004; Lukianenko, Mozhovyi, Hubskyi, 1998). Despite the differences in approaches, the vast majority of scientists identify the basic risks, which are presented in Fig. 2.

However, as practice has shown, there comes a period when one risk completely determines the development of further events, including the formation of the investment attractiveness of the regions. The UN World Investment Report 2020 notes that global flows of foreign direct investment (FDI) have been under great pressure as a result of the Covid-19 pan- demic. Inflows in developing countries have been particularly hard hit. (UN World Investment Report, 2020).

The Covid-19 pandemic has undoubtedly changed and continues to change many characteristics of the economy and society. Together with the onset of the Fourth Industrial Revolution and the transition to the digital era, as well as taking into account completely new realities of the development of future generations, which are regulated by the concept of sustainable development, the formation of investment attractiveness is also taking place in a fundamentally different way. This fact was actively discussed at the 46th International Economic Forum (K. Schwab, S. Zahidi, 2016), and is also clearly visible in the empirical studies of the Association of Certified International Investment Analysts (ACIIA), Colliers International, European Investment Monitor.

For example, the empirical review of the European Investment Monitor for 2018-2020 notes a decrease in the inflow of foreign direct investment (FDI) to Europe, which in 2019 amounted to 6,412 projects, which is $0.9 \%$ more than in 2018 . However, the Covid-19 pandemic contributed to the fact that only 4168 of them were implemented on time, a quarter of 1603 projects were postponed, and a tenth of 614 were canceled. In 2020, instability caused by the 


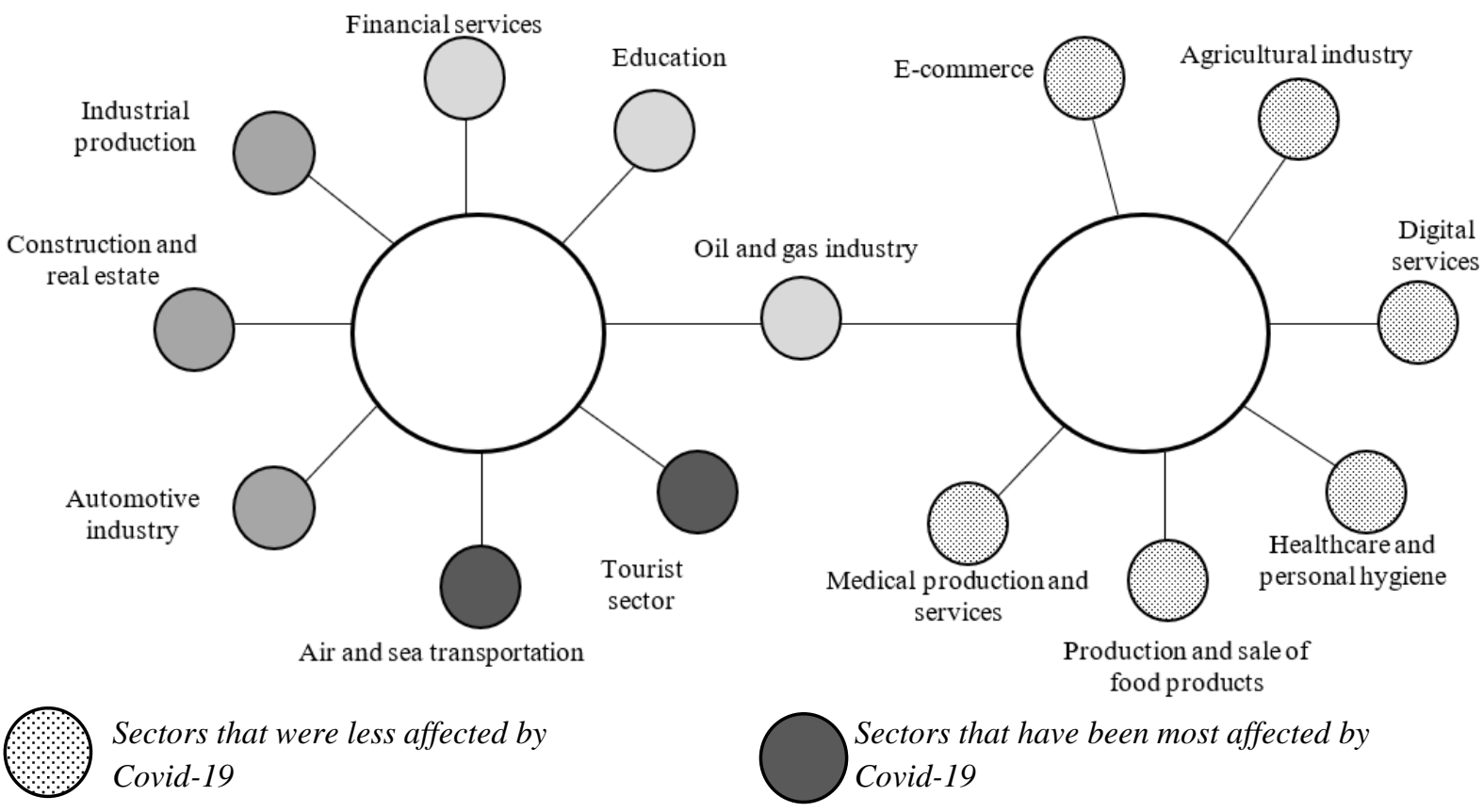

Fig. 5. Inversion of consumer preferences in economic sectors during Covid-19 (compiled by the authors on the basis of OECD, 2021)

spread of coronavirus infection led to another reduction in FDI inflows to Europe by another 13\% (EY, 2019, 2020).

Despite the negative dynamics of FDI in 2019-2020, foreign companies continue to consider Europe as the most stable region with qualified, highly professional labor resources. The infographics of the European regions of the leaders in the number of investment projects in 2019-2020 are presented in (Fig. 3). It follows from the figure that a fifth of all European projects involving FDI account for France, which became the leader in terms of investment attractiveness and activity in 2019. During this period, 1,197 projects were announced in the region, which is $17 \%$ higher than in 2018. Thus, France has displaced the United Kingdom, which has had the highest investment attractiveness in Europe over the past decade. The change of leading positions is explained by the dominant impact of several risks caused by the Fourth Industrial Revolution (+/-), new realities of the development of future generations (+/-), Brexit in the UK (- for the UK/+ for France), the reform of labor legislation and corporate taxation initiated by Emmanuel Macron in 2017, which was highly appreciated by French and foreign investors (- for the $\mathrm{UK} /+$ for France) and the Covid-19 pandemic, which negatively affected investment activity in the world as a whole, and also contributed to the structural transformation of international production. Thus, if in 2016-2017, according to official data from Eurostat, financial and insurance activities accounted for the highest share of both incoming and outgoing FDI flows of the EU-28 (Eurostat, 2016), in 2019-2020, projects in the digital technologies and business services sectors were the most attractive for foreign investors (The Global Risks Report, 2021). The com- bined share of these sectors accounted for a third of all projects and a quarter of all new jobs. (Fig. 4). Despite the fact that the risk of Covid-19 is shortterm (The Global Risks Report, 2021), its negative impact was felt by the whole world. Thus, according to the Global Risks Report -2021, Covid-19 has contributed to reducing the pace of development of the world economy, expanding existing differences within communities and between peoples, thereby complicating the path to achieving peace and the Sustainable Development Goals until 2030 (The Global Risks Report, 2021).

About the impact of the pandemic and the shift in consumer preference in the sectors of economy said in expert reviews of the Organisation for Economic cooperation and Development (OECD), Business confidence index (BCI), according to which Covid19 increasingly negatively affect the tourism sector, the aviation and shipping, and helped enhance the development of e-Commerce, digital services, medical services and medical equipment manufacturing (Fig. 5). Changes in consumer preferences also affected the investment attractiveness of economic sectors. According to the presented image, there are more chances for the implementation of investment projects in those sectors where there is an increase in consumer demand due to the pandemic. It follows from the presented analysis that, despite its shortterm nature (The Global Risks Report, 2021), Covid19 contributed to a decrease in the investment attractiveness of some European regions (Great Britain, Spain, Russia), and the growth of others (France, Germany). The pandemic has led to a structural transformation of international production and consumer preferences, thereby ensuring the growth of capital in some sectors of the economy (medical pro- 

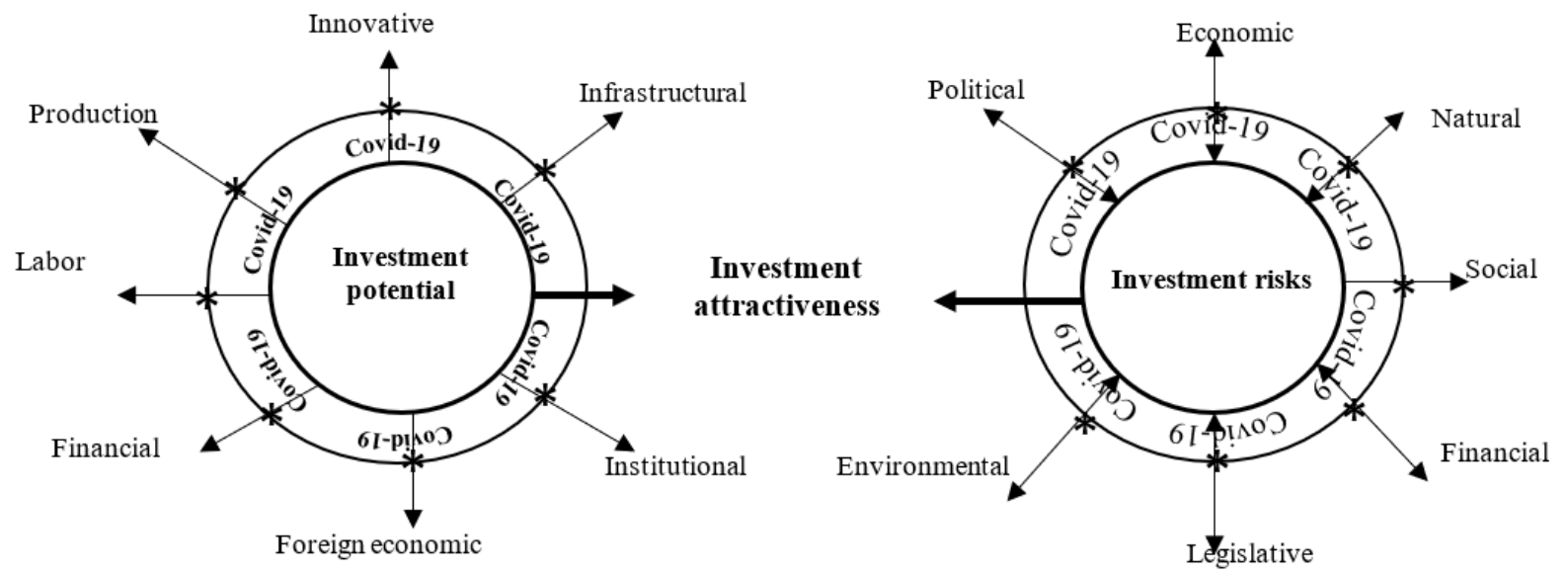

Figure 6. An imaginative model of the formation of investment attractiveness of regions during the Covid-19 pandemic, compiled by the authors

duction and services, digital services, e-commerce) and its reduction in others (tourism, air and sea transportation, the financial sector). In addition, there is still no clarity about the formation of the investment attractiveness of the regions after the Covid-19 pandemic.

The next strains of Delta, Epsilon, accelerated growth of investments in technology development, increased attention to issues of sustainable development and the fight against climate change, force investors to diversify IA. In this regard, some European regions may lose their investment attractiveness, while others, on the contrary, increase it due to the formation of resistance to Covid-19, therefore, the figurative model of the formation of investment attractiveness of regions during the Covid-19 pandemic will have a different look (Fig. 6).

The feature of the modified model of formation of investment attractiveness of the regions during the pandemic Covid-19 is that in addition to the key risks, there is an additional environment formed by the risk of Covid-19, which (Fig. 6) indicated by a circle, and the impact of this environment, formed by the intersection with other risks, weakening or strengthening the impact of each thereof.

\subsection{Formation of sustainable investment attractive-} ness of regions in the conditions of Covid-19: methodological aspect

The analysis of the scientific and methodological basis in the context of the investment attractiveness of the regions allowed us to establish that the process of forming the investment attractiveness of the regions (IAR) in most cases is based on its assessment, by calculating ratings or points, on the basis of which conclusions are made. The most popular methods include the ratings of Euromoney, Forbes, Fitch, Moody's, Standard\&Poor's, Barda's methods, 2003; Sivelkina, 2003; Smaglyukova, 2010; Khusnullina, 2009. As a rule, the listed methods offer the determination of the level of IAR through the amount of profit from investments, through expert assessments, vertical and horizontal analysis of investments, approaches are widely used, within the framework of which an integral, aggregated indicator is derived. It should be noted that the existing methods are based on only two approaches. Therefore, these methods do not fully take into account the regional features of the formation of IA and the specifics of the development of the region, and they also do not take into account the risks affecting the level of IAR.

Thus, the investment ratings of the RA Expert agencies, the Agency for Strategic Initiatives, the National Rating Agency, Euromoney, Forbes, Fitch, Moody's, Standard \& Poor's do not take into account such important characteristics of the IAR as the sectoral structure of the region's economy, and the real level of investment activity in the region does not always correspond to the assigned investment rating, which indicates its insufficient validity. Since the presented methods give preference to the scores set by experts, the results obtained will not be devoid of a certain degree of subjectivity.

The second approach to assessing the investment attractiveness of regions is based on the use of statistical scores, not expert ones. This approach is applied using the reduction of the values of statistical indicators to point indicators with reference to a scale, which also cannot fully reflect the level of difference in statistical indicators by region due to the limited intervals or a previously limited range of point estimates.

In addition, it is established that at this stage of the development of investment activity, in general, there is no methodology for forming a stable investment attractiveness of the regions. All this makes it necessary to develop special scientific and methodological tools for forming the investment attractiveness of regions in the conditions of Covid-19 on the basis of a set of relevant principles, methods and tools that ensure its calculation.

Scientific and methodological support for the formation of investment attractiveness of regions under the conditions of Covid-19 is a procedure for diag- 
Table 1. Summary table of indicators of investment attractiveness of regions

\begin{tabular}{|c|c|}
\hline Components of IA & Indicators \\
\hline $\begin{array}{l}\text { Natural and } \\
\text { resource }\end{array}$ & $\begin{array}{l}\text { Area of the territory, thousand } \mathrm{km}^{2} ; \\
\text { Structure of the territory, thousand } \mathrm{km}^{2} ; \\
\text { Population density, people per } 1 \mathrm{~km}^{2} ; \\
\text { Cadastral value of land; } \\
\text { Quantity and structure of natural resources }\end{array}$ \\
\hline Economic & $\begin{array}{l}\text { Gross regional product (in actual prices), billion US dollars; } \\
\text { Volume of products sold, (goods, services), billion US dollars; } \\
\text { Volume of industrial products sold (goods, services), billion US dollars; } \\
\text { Volume of gross agricultural output, billion US dollars; } \\
\text { Retail trade volume, billion US dollars; } \\
\text { Capital investments (in actual prices), billion US dollars; }\end{array}$ \\
\hline Foreign economic & $\begin{array}{l}\text { Total volume of exports of goods, million US dollars; } \\
\text { Total volume of exports of services, million US dollars; } \\
\text { Total volume of imports of goods, million US dollars; } \\
\text { Total volume of imports of services, million US dollars; } \\
\text { Total volume of direct investments (share capital), million US dollars }\end{array}$ \\
\hline Financial & $\begin{array}{l}\text { Rate of inflation; } \\
\text { Finance of business entities; } \\
\text { Public finance; } \\
\text { Insurance; } \\
\text { Lending. }\end{array}$ \\
\hline Ecological & $\begin{array}{l}\text { Amount of industrial emissions into the atmosphere, tons per } 1 \mathrm{sq} . \mathrm{km} \text {; } \\
\text { Amount of fresh water, cubic km per } 1000 \mathrm{sq} . \mathrm{m} . ; \\
\text { Amount of greenhouse gas emissions; } \\
\text { Share of forest cover; } \\
\text { Specific energy intensity of GDP; } \\
\text { Amount of hazardous waste generated. }\end{array}$ \\
\hline Production & $\begin{array}{l}\text { Net financial result of enterprises before taxation, billion US dollars; } \\
\text { Amount of profit that the enterprises received, billion US dollars; } \\
\text { Number of small enterprises, units; } \\
\text { Number of employed workers at small enterprises, thousand people; } \\
\text { Volume of products (goods, services) sold by small enterprises, US dollars; } \\
\text { Fixed assets, billion US dollars; } \\
\text { Updates of fixed assets, billion US dollars; }\end{array}$ \\
\hline Innovative & $\begin{array}{l}\text { Number of scientific organizations, units; } \\
\text { Number of issued patents, units; } \\
\text { Number of employees involved in the implementation of scientific research, people; } \\
\text { Expenses for the implementation of research and development, million US dollars; } \\
\text { Expenditures on innovations of industrial enterprises, million US dollars; } \\
\text { Volume of innovative products (goods, services) sold by industrial enterprises, million US dollars. }\end{array}$ \\
\hline Labor & $\begin{array}{l}\text { Number of permanent population, thousand people; } \\
\text { Number of economically active population, thousand people; } \\
\text { Number of the employed population, thousand people; } \\
\text { Population of the pre-working age }(0-15 \text { years), thousand people; } \\
\text { Population of working age (16-59 years), thousand people; } \\
\text { Number of employed people with higher education, thousand people; } \\
\text { Number of employees per } 1000 \text { workforce, thousand people. }\end{array}$ \\
\hline Infrastructural & $\begin{array}{l}\text { Number of localities, from; } \\
\text { Volume of cargo transported by road, million tons; } \\
\text { Operational length of railway tracks, thousand km; } \\
\text { Length of public roads, thousand km; } \\
\text { Number of mobile communication subscribers, thousand units; } \\
\text { Number of Internet subscribers, thousand units. }\end{array}$ \\
\hline Consumer & $\begin{array}{l}\text { Volume and structure of consumption; } \\
\text { Market demand; } \\
\text { Real monetary income of the population; } \\
\text { Real wages. }\end{array}$ \\
\hline Social & $\begin{array}{l}\text { Housing security, }{ }^{\mathrm{m} 2} \text {. per } 1 \text { resident; } \\
\text { Density of paved roads and public railway tracks, km per } 1000 \mathrm{sq} . \mathrm{km} ; \\
\text { Number of teachers and doctors per } 1000 \text { population, people; } \\
\text { Number of stadiums with a capacity of more than } 1500 \text { people and flat sports facilities, pcs. per } 1000 \text { popu- } \\
\text { lation. }\end{array}$ \\
\hline Institutional & $\begin{array}{l}\text { Structure of the legal system and the investment management system } \\
\text { Quality of the institutional system } \\
\text { Index of liberalization } \\
\text { Corruption Perceptions Index }\end{array}$ \\
\hline
\end{tabular}

Note: the table does not contain an exhaustive number of indicators, but only the most commonly used ones when calculating the investment attractiveness of regions 
nosing the investment potential of the region and investment risks (one of which is dominant in the short term, and determines the strengthening or weakening of the impact of others) that arise both at the state level and in each individual region, as well as the interpretation of the results based on a comparison of the data obtained (compiled by the author).

The authors understand the stable investment attractiveness of the regions as a set of investment potential (conditions and opportunities), focused on meeting the needs of future generations, and risks affecting the volume of attracted capital.

The basis of the author's methodology for forming the investment attractiveness of regions under the conditions of Covid-19 is based on the adapted development of N. Klimova 2003, which identified three dominant components of investment potential: resource (production + labor + financial resources), infrastructure and institutional ones, believing that they most systematically and fully reflect the components of social production, the subsystem of which is the investment sphere. However, taking into account the fact that modern trends have shifted towards qualitative indicators, in addition to the components of investment potential, the author's methodology identifies three dominates of sustainable development: economic, environmental, social and the dominant risk of Covid-19. Based on this, the procedure for assessing investment attractiveness becomes very cumbersome, since in each block (investment potential, investment risks, dominant risk of Covid-19, sustainable development, etc.) there is a certain set of indicators that are repeated in different blocks and make it difficult to deduce the total result (Table 1).

As follows from Table 1, the number of indicators is diverse and some of them are duplicated. Therefore, their systematization was carried out, as a result of which it was concluded that when developing a methodology for forming a sustainable investment attractiveness of regions under the conditions of Covid-19, it is advisable to be guided by an infrastructure approach.

The authors' understanding of infrastructure is reduced to the definition of the Austrian economist of Polish origin, Rosenstein-Rodan, who proposed to define it as a set of conditions that ensure the favorable development of entrepreneurship in the main sectors of the economy and meet the needs of the entire population (Rosenstein-Rodan P.N., 1969). Thus, the infrastructure approach can be considered as a set of management bodies and institutions that support the main market processes both in an organizational and material way, as well as the economic and financial activities of market structures. The infrastructure approach allows us to organize a large array of indicators without duplicating them, to determine the degree of investment attractiveness of regions, to form reasonable conclusions about the investment prospects for the development of regions.
The adherents of the infrastructure approach also include N. Vasilchuk, E. Kuzmenko (2015); O. Vasyliev (2007); A. Hryshchenko, V. Soboliev (1998); A. Kuznetsova (2013). In particular, in the studies of N. Vasilchuk, E. Kuzmenko the authors distinguish production, non-production, market and institutional infrastructure (Vasilchuk, Kuzmenko, 2015). This idea is used when dividing the investment potential into groups, in order to avoid duplication of indicators, and simultaneously display the components of sustainable development and sustainable investment attractiveness in a comprehensive manner.

The higher the level of infrastructure development in the region, the more attractive it is for investors. Investment attractiveness provides new jobs and cash receipts in the form of taxes to the regional budget. Consequently, there is a steady improvement in the quality of life, which is the main indicator of the economic growth of the region and it ensures the implementation of the sustainable development goals. The procedure for forming a stable investment attractiveness of regions under the conditions of Covid-19 consists of the following blocks (Fig. 7).

As already noted, the procedure for forming a stable investment attractiveness of regions under the conditions of Covid-19 involves the diagnosis of key blocks according to various indicators. Generalization of research in the field of diagnostics made by V. Vasylenko, D. Vasilenko (2013), I. Blank (2004), E. Boichenko (2012), A. Barannikov (1999), B. Kollas (1997), E. Korotkova (2006), O. Hetman, V. Shapoval (2007), allowed us to come to the conclusion that its essence is determined through a triad of approaches, namely: 1) as a component of management activity (at the micro level - an enterprise, organization, institution; at the macro level - a state, region, industry), designed to control, in order to establish deviations in the development of an object from normative indicators and respond to them at the development stage; 2) as the ability to recognize the state of an object based on analysis in order to form reasonable conclusions about the identified trends, problems and causes that cause a negative development trend; 3) as scientific and methodological support, the use of which allows identifying, describing and determining problems in the processes of analysis, synthesis and evaluation.

Based on the above, the diagnosis of the formation of sustainable investment attractiveness of regions under the conditions of Covid-19 is understood by the authors as a complex of scientific, methodological and applied research aimed at identifying, describing and determining problems associated with changing conditions and opportunities for the development of individual elements of investment activity in this territory.

The basis for diagnosing the formation of sustainable investment attractiveness of regions under the conditions of Covid-19 is an infrastructure approach and a matrix method (Fig. 8), 


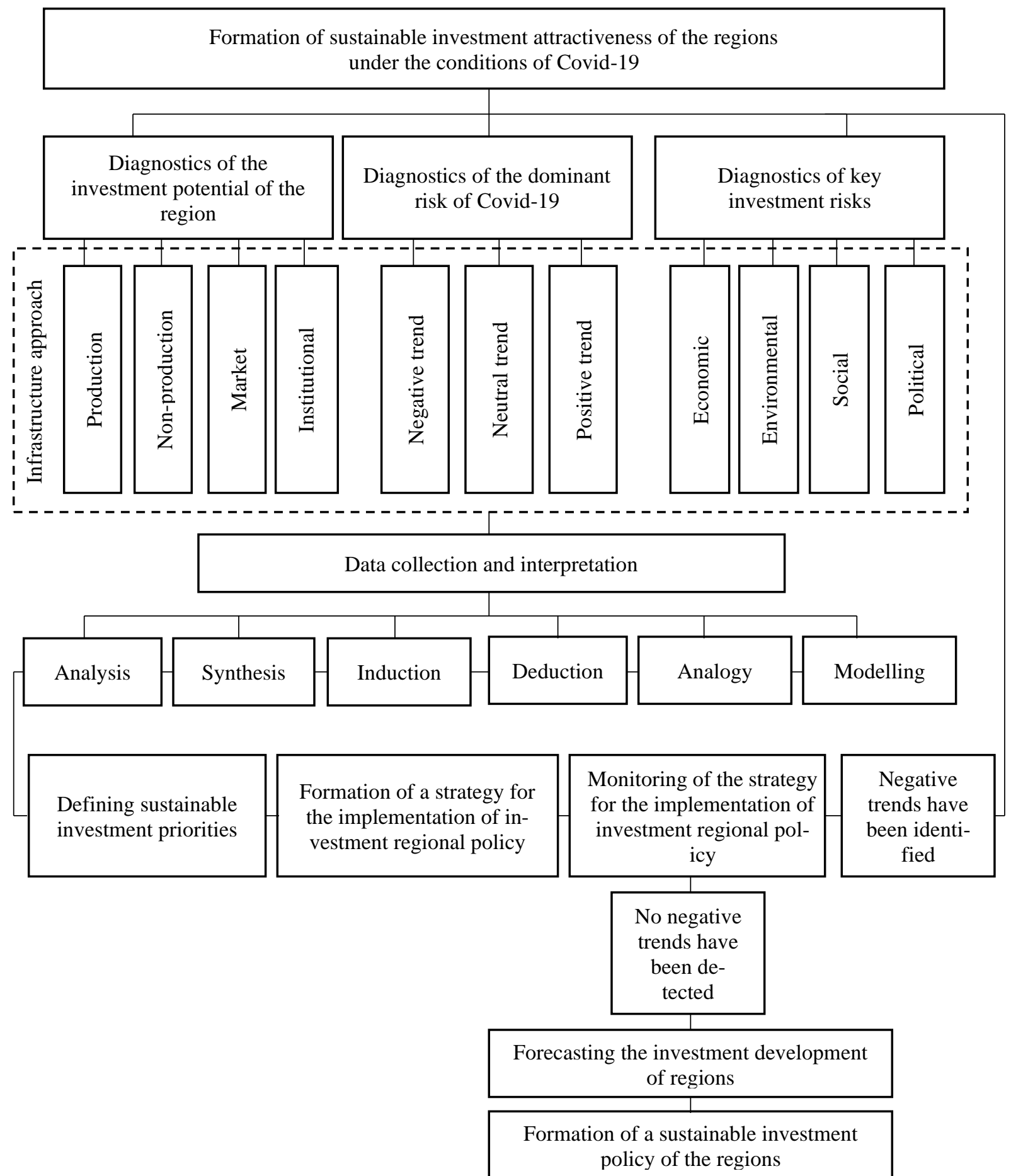

Figure 7. The procedure of formation of a stable investment attractiveness of regions under the conditions of Covid-19, compiled by the authors on the basis of N. Klimova (2003); N. Vasilchuk, E. Kuzmenko (2015)

where, KIR - key investment risks,

DIR - dominant investment risk.

This made it possible to systematize indicators for all blocks (diagnostics of the investment potential of the region, the dominant risk of Covid-19 and key investment risks) in order to avoid their duplication, as well as to clearly interpret the result.

The production component of the investment potential of the region reflects the main trends in the development of production activities in the region and the opportunities associated with this activity. It is determined by the depreciation of fixed assets, roads and railways, the specific weight of paved roads and public railways, the share of unprofitable enterprises, the amount of damage resulting from the impact of Covid, etc.

The non-production component of the investment potential of the region includes social and management components and is determined on the basis of the following indicators: number of employed per 


\begin{tabular}{|l|c|c|}
\hline \multicolumn{3}{|c|}{$\begin{array}{c}\text { Diagnostics of the investment poten- } \\
\text { tial of the region }\end{array}$} \\
\hline Production & $P$ & 1 \\
\hline Non-production & $P^{p}$ & 2 \\
\hline Market & $M$ & 3 \\
\hline Institutional & $I$ & 4 \\
\hline
\end{tabular}

\begin{tabular}{|c|c|c|c|c|}
\hline \multicolumn{5}{|c|}{ Risk diagnostics } \\
\hline \multicolumn{4}{|c|}{ KIR } & DIR \\
\hline 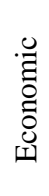 & 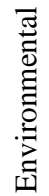 & $\begin{array}{l}\cdot \vec{\pi} \\
0 \\
0 \\
\text { n }\end{array}$ & 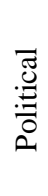 & 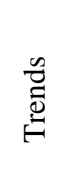 \\
\hline 1 & 2 & 3 & 4 & 5 \\
\hline
\end{tabular}

$\begin{array}{ccccc}P_{11} & P_{12} & P_{13} & P_{14} & P_{15} \\ P^{p}{ }_{21} & P^{p} 22 & P^{p}{ }_{23} & P^{p}{ }_{24} & P^{p} 25 \\ M_{31} & M_{32} & M_{33} & M_{34} & M_{35} \\ I_{41} & I_{42} & I_{43} & I_{44} & I_{45}\end{array}$

Figure 8. Matrix of aggregation of variables of sustainable investment attractiveness of regions under the conditions of Covid19 , compiled by the authors on the basis of Lagler (2021)

1000 workforce, proportion of the population with monetary incomes below the subsistence minimum, housing security per 1 inhabitant, area of emergency housing stock, number of teachers and doctors per 1000 population, etc. The management component in this case is determined through such characteristics as: insufficient volume of attracting investments for further economic development (the ratio of direct investment in GRP), errors in the development and management of regional budget programs; the inability of regional authorities to provide or partially limit the population with the necessary level of social services, as well as the level of corruption in public administration.

The market component of the investment potential of the region combines organizational, technical, financial, credit and research components, each of which performs certain functions (N. Vasilchuk, E. Kuzmenko, 2015) and has its own set of indicators. Thus, the function of the organizational and technical component is to coordinate the relationship between the market and society. The system of indicators of the market component, in turn, is divided into several groups. Taking into account the fact that this study is devoted to the formation of the investment attractiveness of the regions, the main indicators of the organizational and technical component include the provision of enterprises with raw products, materials, equipment and other goods and services and the organization of sales of manufactured products through various channels of the sphere of circulation, the number of enterprises engaged in the sale and storage of goods and their distribution by types and kinds thereof, the size of trading enterprises, as well as throughput.

The main function of the financial and credit component is the accumulation of temporarily free monetary resources and their redistribution through lending. Based on this, it is advisable to present such indicators as the return on capital of enterprises in the basic sectors of the economy, the number of loans issued by banks by type of activity, the increase in assets of credit institutions, the volume of PI by economic sectors, and in the regional context.

The research component provides consulting services to entrepreneurs, investors, training of specialists in the investment field (conducting trainings, seminars, courses, etc.), research of market conditions and its dynamics, forecasting the state of markets, etc. The research component of the market component is characterized by such indicators as capacity, market saturation, production, import, export volumes, the number of specialists in the investment sphere, the number of types of educational activities and programs, the number of internationally accredited programs, expertise, etc.

In this case, the institutional component of the investment potential of the region is considered as a specific system of generally accepted, legally and traditionally established regulations, rules and restrictions, the organization, formation, regulation and use of which ensures the functioning of the market system in order to form a stable investment attractiveness of the regions under the conditions of Covid-19. 
Table 2. Typology of trends in sustainable investment attractiveness of regions in the context of Covid-19, compiled by the authors based on Boichenko, Vasilchuk (2017)

\begin{tabular}{|c|c|}
\hline Characteristics & Conclusions \\
\hline \multicolumn{2}{|c|}{ Negative trend } \\
\hline $\begin{array}{l}\text { It indicates the presence of a problematic situation in the } \\
\text { epidemiological situation, which negatively affects the } \\
\text { formation of a stable investment attractiveness of the re- } \\
\text { gions under the conditions of Covid-19. }\end{array}$ & $\begin{array}{l}\text { The number of sick people is increasing; the number of those } \\
\text { who have recovered is decreasing, as well as mortality is in- } \\
\text { creasing. }\end{array}$ \\
\hline \multicolumn{2}{|l|}{ Zero trend } \\
\hline $\begin{array}{l}\text { It gives an idea of the situation in which the dynamics of } \\
\text { the main indicators characterizing the epidemiological sit- } \\
\text { uation did not change during the study period in practice. }\end{array}$ & $\begin{array}{l}\text { There are no changes in the number of cases, recovered and } \\
\text { deaths from Covid-19 during the study period. }\end{array}$ \\
\hline \multicolumn{2}{|c|}{ Positive trend } \\
\hline $\begin{array}{l}\text { It indicates the presence of positive phenomena and pro- } \\
\text { cesses in the epidemiological situation, which favorably } \\
\text { affects the formation of a stable investment attractiveness } \\
\text { of regions under the conditions of Covid-19. }\end{array}$ & $\begin{array}{l}\text { The number of cases is decreasing (or there are no new cases); } \\
\text { the number of recovered patients is increasing, mortality is de- } \\
\text { creasing (or there are no new cases). }\end{array}$ \\
\hline
\end{tabular}

Production, non-production, market and institutional components are formed under the influence of key investment risks (KIR), which include: economic, environmental, social and political risks, and the dominant investment risk of Covid-19 (DIR).

The risks, as well as the indicators of the investment attractiveness of the regions, were systematized, since there is a wide variety of classifications and types of risks in the modern scientific literature. In this study, the risks are divided into two groups: key and dominant ones. Under key investment risks, the authors understand those risks that are most dependent on external factors and that are most difficult to manage. The division of risks into two groups, among other things, is due to the concept of sustainable development, under the influence of which socio-economic processes are formed in the modern world (including the formation of the investment attractiveness of the region).

Diagnostics of economic risks in the context of sustainable development is based on the theory of maximum total income, which can be achieved through the optimal use of limited resources, saving technologies and cost reduction. The indicator of sustainability in this case is the independence of the region, which is ensured by the formation of a stable investment attractiveness.

Diagnostics of environmental risks implies that investment activities and processes associated with it should not violate the integrity of natural systems (natural systems should also be understood as the environment created by men, for example, cities). Environmental risks arise due to environmental pollution, man-made disasters caused by technical and technological features of human production and economic activity, as well as due to the accumulation of a large amount of industrial and household waste; emissions into the atmosphere, the use of mineral fertilizers and plant protection products in agriculture, etc. Environmental pollution leads to a decrease in the ability of natural systems to renew, which is an obstacle to sustainable development. Therefore, the main purpose of diagnosing environmental risks is to form a sustainable investment attractiveness of regions based on the principles of regional sustainable development (see Fig. 1).

Diagnostics of social risks involves the identification (prevention) of destructive conflicts in society caused by investment processes and violating the stability of social and cultural systems. An indicator of sustainability in this case is an effective and fair decision-making system, a fair distribution of investment potential and investment benefits.

The diagnostics of political risks is aimed at ensuring consistency between the components of sustainable development; the investment attractiveness of the region; the components of sustainable development and investment attractiveness, as well as ensuring their integration from the fundamental to the applied plane. Political risks arise due to corruption, the lack of flexible legislative support for investment activities; the absence or imperfect territorial legislation coordinating privileged investment conditions that lead to social aggression (protests, strikes), military actions (revolution, external aggression). An indicator of sustainability in this case is an effective regulatory framework.

Diagnostics of the dominant risk of Covid-19 involves determining the strength of its impact by periods (establishing a trend for a month, quarter, halfyear, year). It is worth noting that the dominant risk is the risk that has caused a significant undesirable impact on all spheres of life in a short period of time and has caused significant changes in the present and future periods. As indicators on the basis of which trends are formed (Table 2) it is proposed to use the population of the region, the number of cases of Covid-19, the number of recovered after Covid-19, the mortality from Covid-19.

Diagnostics of investment potential and investment risks is based on the collection and interpretation of data, using an integrated approach that includes such methods (Table 2).

Thus, the diagnostics of the sustainable investment attractiveness of regions under the conditions of Covid-19 allows us to form a comprehensive system 
Table 3. Methods of diagnostics of stable investment attractiveness of regions under the conditions of Covid-19, compiled by the authors on the basis of Sheremet (2014)

\begin{tabular}{|c|c|c|}
\hline Method & Characteristics & Result \\
\hline Analysis & $\begin{array}{l}\text { With the help of analysis, we establish the reality behind the } \\
\text { totality of phenomena. The analysis allows us to reveal the } \\
\text { essence of investment processes in the region, to understand } \\
\text { the existing relations between investors, entrepreneurs, the } \\
\text { state, intermediaries, etc., to find out the reasons for the emer- } \\
\text { gence of these relations and the trends of their development. }\end{array}$ & $\begin{array}{l}\text { The division of the total set of investment } \\
\text { processes associated with the formation of } \\
\text { the investment attractiveness of the region } \\
\text { and the formation of conclusions for each } \\
\text { component separately. }\end{array}$ \\
\hline Synthesis & $\begin{array}{l}\text { Using the synthesis, we combine the previously selected parts } \\
\text { of the investment attractiveness of the region into a single } \\
\text { whole. The synthesis allows us to determine how (with what } \\
\text { force) the investment potential, investment risks, and domi- } \\
\text { nant risk affect the formation of the investment attractiveness } \\
\text { of the region. }\end{array}$ & $\begin{array}{l}\text { Combining the data obtained as a result of } \\
\text { the analysis. Justification of the strength (de- } \\
\text { gree) of intensity and direction (tendency) of } \\
\text { the influence of some processes and phe- } \\
\text { nomena on others. }\end{array}$ \\
\hline Induction & $\begin{array}{l}\text { With the help of induction, we obtain general judgments, } \\
\text { which are empirical and theoretical laws, hypotheses, general- } \\
\text { izations. For example, we substantiate the dependence of the } \\
\text { environmental and social components of sustainable develop- } \\
\text { ment on the investment attractiveness of the region. }\end{array}$ & $\begin{array}{l}\text { Building a general conclusion based on pri- } \\
\text { vate conclusions }\end{array}$ \\
\hline Deduction & $\begin{array}{l}\text { It is the opposite of induction and represents a transition from } \\
\text { the general to the particular. For example, based on the study } \\
\text { of the investment attractiveness of the region, its impact on the } \\
\text { amount of emissions into the atmosphere, the number of jobs } \\
\text { and the level of income of the population, etc. is determined. }\end{array}$ & $\begin{array}{l}\text { Construction of the further course of empir- } \\
\text { ical research (new inductive generaliza- } \\
\text { tions). }\end{array}$ \\
\hline Analogy & $\begin{array}{l}\text { Using analogy, we draw conclusions by comparing different } \\
\text { regions with each other, identifying similar features, and by } \\
\text { comparing them we come to a specific conclusion. For exam- } \\
\text { ple, the generalization of the experience of forming the invest- } \\
\text { ment attractiveness of Asian countries in order to implement it } \\
\text { in European regions. }\end{array}$ & $\begin{array}{l}\text { Forming conclusions about one object based } \\
\text { on drawing an analogy with other objects. }\end{array}$ \\
\hline Modelling & $\begin{array}{l}\text { Conclusions by analogy, understood very broadly as the trans- } \\
\text { fer of information about some objects to others, constitute the } \\
\text { epistemological basis of modeling, which involves the study } \\
\text { of investment attractiveness by creating and researching a } \\
\text { copy (model) that replaces the original from certain sides of } \\
\text { cognition. }\end{array}$ & $\begin{array}{l}\text { Formation of conclusions based on the con- } \\
\text { struction of the model. }\end{array}$ \\
\hline $\begin{array}{l}\text { Forecast- } \\
\quad \text { ing }\end{array}$ & $\begin{array}{l}\text { With the help of forecasting, we obtain qualitative and quanti- } \\
\text { tative characteristics of investment potential and investment } \\
\text { risks. }\end{array}$ & $\begin{array}{l}\text { Drawing conclusions about the prospects for } \\
\text { the formation of a sustainable investment } \\
\text { policy in the region. }\end{array}$ \\
\hline
\end{tabular}

for monitoring changes and determine sustainable investment priorities, which are further reflected in the strategy for implementing regional investment policy. Further, it is necessary to conduct a practical testing of the strategy in order to identify deviations based on monitoring. If a negative trend is determined, a repeated diagnosis is carried out, on the basis of which the reasons that negatively affect the formation of investment attractiveness are established.

\section{Conclusion}

In the article, based on the results of the conducted research, the theoretical and methodological foundations for the formation of sustainable investment attractiveness of regions under the conditions of Covid-19 are formed.

Based on the generalization of scientific points of view, it is established that investment attractiveness determines the vectors of investment movement and consists of investment potential and investment risks. The formation of the investment attractiveness of regions is carried out under the influence of various groups of risks, the set of which changes over time, just as the strength of their influence either increases or decreases. 2019 has shown that a period is coming when one risk (Covid-19) completely predetermines the behavior of other risks and, in general, further socio-economic development. In this regard, there is a need to introduce such a term as sustainable investment attractiveness. It is proposed to understand the stable investment attractiveness of the regions as a set of investment potential (conditions and opportunities), focused on meeting the needs of future generations and risks affecting the volume of attracted capital.

Based on an analytical review of investment flows in European regions before and during Covid-19, it is proved that the pandemic has changed and continues to change many characteristics of the economy and society. It is proved that together with the onset of the Fourth Industrial Revolution and the transition to the digital era, as well as taking into account com- 
pletely new realities of the development of future generations, which are regulated by the concept of sustainable development, the formation of investment attractiveness is also taking place in a fundamentally different way. In this regard, there is a need to develop organizational and methodological support for the formation of sustainable investment attractiveness of regions under the conditions of Covid-19. A figurative model of the formation of the investment attractiveness of regions during the Covid-19 pandemic is proposed, which, unlike the existing ones, in addition to the key risks, contains an additional environment formed by Covid-19.

Based on the analysis of the scientific and methodological basis in the context of the investment attractiveness of the regions, it is established that the process of its formation in most cases is based on an assessment, by calculating ratings or points, on the basis of which conclusions are made. It is proved that the existing approaches do not fully take into account the regional features of the formation of investment attractiveness, the specifics of their development, do not focus on risks, and the results obtained are devoid of a certain degree of objectivity. This led to the development of a clear procedure for the formation of a stable investment attractiveness of regions under the conditions of Covid-19, which, unlike the existing ones, allows us to form a comprehensive system for monitoring changes and determine sustainable investment priorities.

\section{References}

1. ASAUL A., PASYADA I., 2004, Systematization of factors characterizing the investment attractiveness of regions, Regional Economics, no 2: 53-62.

2. BEVAN A., S. ESTRIN, K. MEYER, 2000, Institution building and the integration of eastern Europe in international production, Centre for New and Emerging Markets, Discussion paper series, no 11, London Business School.

3. BEZRUKOVA T., SHANIN I., ZIBOROVA YA., 2015, Factors of assessing investment attractiveness, International Journal of Applied and Basic Research, 3(3): 415-418

4. BOICHENKO E., VASILCHUK N. Monitoring of international donor support in the context of development of the united territorial communities, 2017, Baltic Journal of Economic Studies, 3(5): 25-32.

5. BORSCH L., GERASIMOVA S., 2007, Investment: theory and practice, Knowledge, Kiev.

6. Eurostat, 2016-2018, https://ec.europa.eu/eurostat/ statistics-explained/index.php?title=Foreign_direct_ investment_-_flows\#Recent_developments_in_EU28_FDI_flows (26.08.2021).

7. EY European Investment Monitor 2020, June 2021, https://www.ey.com/ru_ru/attractiveness/21/european-attractiveness-survey-2021 (26.08.2021).

8. Geographical encyclopedia, Natural conditions, https ://dic.academic.ru/dic.nsf/enc_geo/ (08.06.2021).

9. GRISHINA I., SHAKHNAZAROV A., ROIZMAN I., 2001, Comprehensive assessment of investment attractiveness and investment activity of Russian re- gions: a method for determining and analyzing relationships, Investment in Russia, 4: 5-16.

10. Guiding Principles for Sustainable Development of the European Continent, 2000, Hanover, https://rm.coe.int/1680700173 (12.07.2021).

11. HELLMAN J., JONES G., KAUFMANN D., SCHANKERMAN M., 2000, Measuring governance and state capture: The role of bureaucrats and firms in shaping the business environment, World Bank Working Paper no. 2312, Washington DC.

12. HOLLAND D., PAIN N., 1998, The Diffusion of Innovations in Central and Eastern Europe: A Study of the Determinants and Impact of Foreign Direct Investment, NIESR Discussion Paper no. 137, National Institute of Social and Economic Research, London.

13. JANSSEN RISK, 2001, Management of investments in Joint Implementation and clean development mechanism projects, Ph.D. thesis, University of St. Gallen, Switzerland.

14. KIRYUKHIN V., 2006, Investment risk in the analysis of investment attractiveness, Problems of Modern Economics, 3(19): 87-94.

15. LAVRESH I., MIRONOV V., SMIRNOV A., 2011, Cognitive modeling of socio-economic ratings of regions, Bulletin Itark, 1(1): 22-30.

16. LAGLER K., 2021, Organizational support of investment attractiveness of the economy of the regions of Ukraine, https://drive.google.com/file/d/1dpkQt2C0 zhrcgoZ 80aiWbdme6NMxXbM/view (04.09.2021).

17. MAMONOVA K., 2008, Investment attractiveness as a necessary component of the investment process: conceptual approaches to its definition and analysis, Economics: problems of theory and practice, 235 (IV): 844-853.

18. NOSOVA O., 2003, Estimation of investment attractiveness of Ukraine: basic approaches, Economics and Forecasting, 3: 119-137.

19. Organisation for Economic Co-operation and Development (OECD), 2021, Business confidence index (BCI), https://www.oecd.org/ (25.08.2021).

20. ROBERT B. STOBAUGH, 1969, How to Analyze Foreign Investment Climates, Harvard Business Review, 1: 100-108.

21. ROSENSTEIN-RODAN P.N., 1969, Criteria for Evaluation of National Development Effort, Journal of development planning, 1(1): 1-13.

22. SHEREMET A.D., 2014, Comprehensive analysis of indicators of sustainable development of an enterprise, Economic analysis: theory and practice, 45: 210.

23. The Global Risks Report, 2021, 16th Edition, World Economic Forum, http://www3.weforum.org/docs/ WEF_The_Global_Risks_Report_2021.pdf (27.08.2021)

24. UN World Investment Report 2020, https://unctad. org/system/files/official-document/wir2020_overvie w_ru.pdf (26.08.2021).

25. VASILCHUK N., KUZMENKO E., 2015, Market infrastructure as an integral element of infrastructure system, European Reforms Bulletin, 3: 25-28.

26. VDOVIN S. M., 2014, Investment attractiveness as a factor of sustainable development of the region, Economic Analysis: Theory and Practice, 41(392): 2027.

27. ZADOROZHNA YA., DYADECHKO L., 2007, Increasing the investment attractiveness of entrepreneurship as a direction of attracting investment resources, Investments: practice and experience, 2: 3235 . 